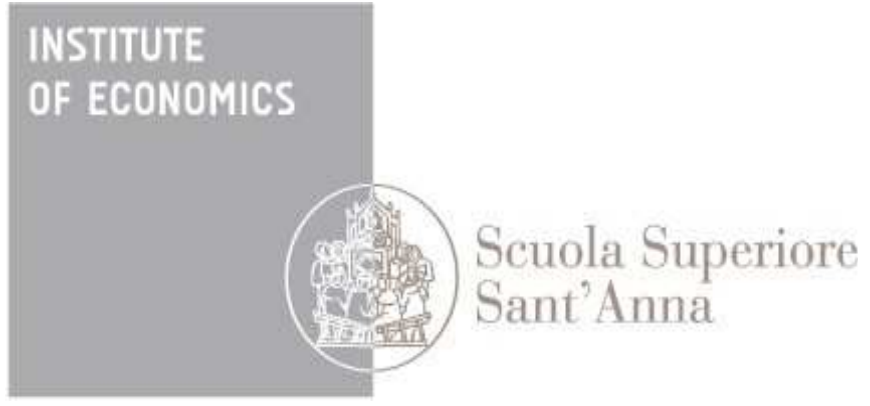

LEM | Laboratory of Economics and Management

Institute of Economics

Scuola Superiore Sant'Anna

Piazza Martiri della Libertà, 33 - 56127 Pisa, Italy ph. +3905088.33 .43$

institute.economics@sssup.it

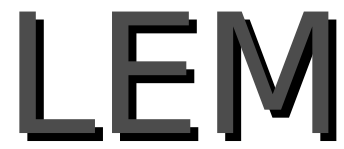

Working Paper Series

\title{
Austerity and Repressive Politics: Italian Economists in the Early Years of the Fascist Government
}

Clara E. Mattei ${ }^{\circ}$

- Institue of Economics, Scuola Superiore Sant'Anna, Pisa, Italy

\section{5/17 June 2015}

ISSN (online) 2284-0400 


\section{Austerity and Repressive Politics: \\ Italian Economists in the Early Years of the Fascist Government}

\section{Clara Elisabetta Mattei ${ }^{1}$}

Scuola Superiore Sant'Anna, Institute of Economics.

The historical forerunners of contemporary austerity are still largely unexplored. This essay considers the "liberal phase" of Fascist Italy (1922-1925) as a case study to explain austerity as a full-blown rationality, that is intrinsically, and simultaneously, theory and practice, encompassing the moral, the economic and the political. My explanation moves beyond the interpretation of austerity as the post-1980, neoliberal recipe of price deflation and budget cuts. The Italian case draws attention to a neglected connection: that between austerity and repression. Austerity was the guiding principle of the Fascist economic agenda during the 1920s. It served to extinguish the effects of the democratization process of the post-WWI years. The paper examines the work of four distinguished economists, Maffeo Pantaleoni, Luigi Einaudi, Alberto De Stefani and Umberto Ricci, who - in different roles as professors, journalists, advisors, and policy-makers - can be considered the source, the guardians and the enforcers of Fascist austerity.

Key Words: Austerity, Repressive Politics, Economists as Consultants, Fascism.

JEL Classification: B 41, N 44, N 14, B 13

\section{Acknowledgments}

I would like to thank Giovanni Dosi, Alessandro Nuvolari, Pierluigi Ciocca, Claude Diebolt, George Peden, Anwar Shaikh and Adam Tooze for all their valuable ideas in developing and improving this project. A special thanks to Nicola Giocoli for his support and advice throughout the research and writing process. I am grateful to the participants to the HPPE seminars (2015) at the London School of Economics for insightful comments. All shortcomings are my own.

\footnotetext{
1cm3448@columbia.edu
} 


\section{Introduction}

The historical forerunners of contemporary austerity are still greatly unexplored. To address this lacuna, I will show how the "austerity rationality" ${ }^{2}$ is a powerful heuristic to explain the political and theoretical conditions of Italy in the aftermath of World War I. In particular, I demonstrate how a comprehensive study of austerity, both as theory and as a practice, reveals its entanglement with the repressive politics that Fascism put into place. The structural connection between austerity and social repression has failed to be theorized or even significantly recognized, hindering critical thought about the present.

Previous scholarship has described the years of Minister De Stefani's policies (19221925) as "liberal" (Toniolo 1980; Ciocca and Toniolo 1976; Bini 2000; Zamagni 1990). However, no one has attempted a first-hand reconstruction of the common logic of austerity of the men who pursued the economic reforms during those years. I will show that the first phase of the Fascist policies embodied, in essence, an austerity agenda.

The fathers of such reforms were the best-established economists of the time. They came from both Fascist and Liberal backgrounds. I have thus chosen to study four of the most representative. ${ }^{3}$ Two of them, Alberto De Stefani and Maffeo Pantaleoni, were prominent Fascists. Founding father of Marginalism, Pantaleoni was surely the most renowned Italian economist at the time. De Stefani became the first Fascist Minister of Finance and Treasury (1923-1925) and gained "full powers" to enact austerity measures. The remaining two, Umberto Ricci and Luigi Einaudi, shared a liberal political identity. As primary advisor to De Stefani, Ricci actively promoted austerity measures until exile in 1928 after distancing himself from Fascism. Einaudi was both Senator of the Reign of Italy and a prolific journalist. He became the leading representative of the Liberal party in the Italian Constitutional Assembly (1946), and was first Elected President of the Republic (1948). I consider both their political and academic writings. The austerity rationality can only be grasped by uncovering the theoretical basis of concrete actions. This case study shows that knowledge and politics, as well as theory and practice, are unseverable. My goal is to demonstrate that the four economists endorsed austerity because of solid theoretical foundations that were moral and economic, not mere contingencies of their time.

\footnotetext{
2 The term austerity "rationality," rather than rationale, has been chosen to stress the relationship between austerity policies and standard economic rationality, an all-encompassing view that weds practical policies and economic theory.

${ }^{3}$ For secondary literature and details on the four authors, also within the broader context of Italian economics of the time, see Faucci, 2014, Ch.6-7.
} 
The connection between austerity and repressive politics is particularly interesting in the Italian case. Fascist austerity became a powerful means to stop the democratization process that the turmoil of World War I had generated. Furthermore, austerity policies were a crucial means to achieve the normalization process of Fascism. In fact, many respectable sections of the Italian establishment accepted the violent and murderous nature of the Fascist movement in the name of economic stabilization and financial rigor.

Before entering into a discussion of the Italian case, a clarification on the meaning of austerity is necessary. Although the term "austerity" is widely used today in public and academic discussion, semantic vagueness persists. Suzanne Konzelmann, who recently edited the most complete work on the topic, denounces the such lack of precision: "With increasingly strident demands for austerity - and equally vociferous arguments against - one might assume that the definition of austerity, its objectives and effects, are clearly understood...Yet this lengthy debate has failed to produce general agreement about what austerity is, much less when it should be applied" (Konzelmann (2014) p. xvi).

A broad consensus exists on the classification of austerity as a form of economic policy typical of neoliberal economic wisdom. ${ }^{4}$ Most scholars define austerity as an active policy of budget cuts and price deflation, which aims to gain investors' confidence and achieve economic competitiveness. ${ }^{5}$

This interpretation makes it difficult to disentangle austerity policies from neoliberal thought, the former often perceived as derivative of the latter. Hence, austerity loses historical depth and becomes ill suited for historical analysis. In fact, many present critical studies focus on the nature and the effects of neo-liberalism, reducing austerity to a mere appendix of such a paradigm. ${ }^{6}$

4 "Neoliberalism represents a set of ideas that caught on from the mid to late 1970s, and are famously associated with the economic policies introduced by Margaret Thatcher in the United Kingdom and Ronald Reagan in the United States following their elections in 1979 and 1981. The 'neo' part of neoliberalism indicates that there is something new about it, suggesting that it is an updated version of older ideas about 'liberal economics' which has long argued that markets should be free from intervention by the state. In its simplest version, it reads: markets good, government bad," (Campbell, Parker, Ten Bos 2005, 100).

5 "Whilst the term 'austerity' generally refers to forms of cutting back, notably with respect to consumption, from the perspective of policy, the aim of economic austerity is to reduce a country's deficit - the difference between what the government spends and the revenue it earns. Austerity measures therefore include some combination of public expenditure reductions and higher tax proceeds," (Konzelman 2014, xiv). Similarly Marc Blyth writes: "Austerity is a form of voluntary deflation in which the economy adjusts through the reduction of wages, prices, and public spending to restore competitiveness, which is (supposedly) best achieved by cutting the State's budget, debts and deficits," (Blyth 2013,2).

${ }^{6}$ It is known that Foucault and his followers focus upon neoliberalism as a form of governmentality, in particular the two cases of German ordo-liberalism and American neo-liberalism. See Foucault 2008, Dierdot and Laval 2013. 
I suggest that, if correctly theorized and disentangled from vague notions of neoliberalism, austerity becomes a more fine-grained heuristic than neo-liberalism to grasp the policies and practices of both past and present. I do not reduce austerity to an economic policy, but rather consider it in a broader sense as a regime du savoir, or regime of truth (Foucault 2008). It is a form of rationality indistinguishable from a set of practices that constitute a technique of power exercised in a particular historical moment and place. This methodology situates the process of theorizing in a historical-economic space. Theory is inescapably embedded within socio-economic relations. The Italian case in the 1920s shows that economic knowledge is never pure or neutral, but, "an element of government itself which helps to create a discursive field in which exercising power is 'rational'" (Lemke 2000, 8). There is always a reciprocal constitution between power techniques or practices and forms of knowledge, even the technical knowledge of economic science.

Part I recounts historical facts: the Italian Fascist economic agenda of the 1920s embodies austerity. The latter signified a drastic change of direction, since economic reforms brought the post-war distributive trend to an abrupt halt. Part II introduces the economists that had primary influence in the rationalization and implementation of the Fascist austerity policies. The austerity rationality emerges from the combined study of their scientific and engagés works. It is the endorsement of such a logic of repression that unites economists of both Fascist and Liberal convictions. Part III and IV explore the various spheres where a liaison between repression and austerity holds: at the political level, a strong government and at the individual level, in regard to self-restraint. The closing section provides an explanation of the underlying methodological-ontological grounds for the repressive nature of austerity.

\section{Austerity Policies During the Twenties}

Italian liberal governments made efforts to balance the budget in 1921-1922 (Frascani 1975, Toniolo 1980, Ch. II, Ciocca 2007, Ch VII), but it was only during the Fascist years that the country's economic agenda embodied austerity. Fiscal austerity peaked between 1922 and 1925. These years, in which Alberto De Stefani led the Ministry of Treasury, are known as the normalizing phase of the Fascist government. Monetary austerity characterized the second half of the decade, calling for fiscal rigor and wage deflation. Before introducing such policies, it is necessary to call attention to the severe change of direction they represented for the Italian economy. 


\section{I.I The Democratizing Process and the Welfare State}

WWI had great socio-political significance for the allied countries, and in Italy, it fostered the development of a welfare state. Two detailed empirical studies of Alberto De Stefani, La legislazione economica della guerra and L'azione dello Stato italiano per le opere pubbliche, offer evidence of the Italian political-economic transformation as a result of the war.

The effects of WWI induced the State to take a new active role in the organization and protection of labour. Public intervention became the means to correct economic disequilibrium occurring in the labour market. The Italian Government implemented a variety of measures, mostly in the public work sector: "However, the ordinary tendency is the resort to the so called Labor policy, that is epitomized in the acceleration of already approved public procurements, in the execution of new public works and in financial provisions that make the execution of this plan for labor possible,"7 (De Stefani, 1926, 5) De Stefani wrote.

The introduction of the uffici di collocamento di mano d'opera $(1916)^{8}$ (employment bureaus) improved the organisation of labour. Various forms of subsidies for the unemployed furthered the labour policies' goals. Local administrations had a crucial role in such initiatives. Scholarship shows Italy's cutting-edge agenda (Alberti 2013, Alber 1983 ): In 1919, subsidies of involuntary unemployment were extended to all workers in both agriculture and industry until the end of the year. A legislative decree of October 1919 introduced official mandatory insurance against unemployment.

Other forms of social welfare were born at the time: provisions to protect needy families, ${ }^{9}$ credits for the poor and pensions for war orphans (De Stefani 1926a, 41-97) and invalids. In April 1919, insurance against disability and old age became mandatory and covered all private sector workers, more than 10 million people. (Regal decree 21 April 1919, n. 603). Local administrators had an extensive role in exercising these welfare objectives (De Stefani 1926a, 388-389).

\footnotetext{
${ }^{7}$ All translations are mine.
}

8 "When the National Bureau took charge of the hiring services and of the unemployment insurance, job placement became more solidly connected to the assistance of involuntary unemployment (Royal decree 19 October 1919, n. 2214)" De Stefani 1926a, 18.

9 "The charitable activity is carried out in three spheres that are theoretically distinct: 1) unemployment 2) family income imbalances due to war drafting 3) family income imbalances due to price fluctuations," De Stefani 1926a, 10. 
WWI initiated a strong democratization process in the country. Demonstrations and social tensions of workers and peasants reached their peak during the Biennio Rosso (the Two Red Years) ${ }^{10}$, and give proof of rising political awareness.

In February 1919, the government passed an eight-hour-a-day labour law, and introduced minimum wage later that fall. Furthermore, nominal and real wages sharply increased: between 1919 and 1920, real salaries rose about 50\%. ${ }^{11}$ Journeymen in agriculture obtained the legal guarantee of a minimum number of working hours, to be bargained with unions. Legalization of occupied lands in the center-south of Italy occurred in September 1919. ${ }^{12}$ Social redistribution increased to the detriment of private capital. The influence of the October Revolution was palpable: "securities on shares and obligations had to be mandatorily registered, ordinary and extraordinary progressive taxation on income, wealth and inheritance, the establishment of a board of enquiry on military expenditures, the total devolution of war profits to the State, taxation on luxury goods, as motorcycles, cars and motorboats: these and other measure surely did not appeal to the wealthy classes" (Ciocca 2007, 189).

After the march on Rome in October 1922, Mussolini's first cabinet brought the democratizing trend to an abrupt halt. Austerity became the guiding principle, supplanting hard-won social reforms.

\section{I.II Austerity Measures Under Fascism}

With his first speech in Parliament (16 November 1922) Mussolini made it clear that his primary economic objective was to balance the budget:

The directives of domestic policies are epitomized by these words: thrift, labour, discipline. The financial problem is crucial: the budget has to be balanced as soon as possible. Austerity regime: ${ }^{13}$ spending intelligently, helping national productive forces, ending all war controls and state interferences. (Mussolini 1933, 22)

\footnotetext{
${ }^{10}$ For a history of the social uprisings of the time see Ciocca (2007), Ch. VII; Tasca (1965),Vol.1, Ch. II, Vivarelli (1991), Vol. 1 Ch. 5, Berta (1993).

11 "From the data, more precise for industry, it appears that from the beginning to the end of 1919, the increase of the hourly nominal salary was of approximately $30 \%$ while the cost of living increased $30 \%$. From December 1919 to December 1920, the increase of nominal hourly salary was o $84 \%$, with respect to a rise of the cost of living of 46 percent," Ciocca (2007), 187.

12 The Decree was drafted by the Minister of Agriculture Achille Vecchi; the occupations that were legally recognized concerned uncultivated land or state-owned land.

${ }^{13}$ Literally: "regime della lesina" where "lesinare" is synonymous with the verb "to economize."
} 
Mussolini's words represented the common ground for moderate and liberal public opinion: the majority of the national press depicted Mussolini as the only one capable of rebalancing the economy (De Felice 1966, 390). Many influential liberal economists and politicians were ready to test the leader's ability to normalize their financial situation ${ }^{14}$. The budget was balanced by the end of the 1926 fiscal year, the 30th of June.

On December 3, 1922 a royal decree sanctioned the delegation of "full powers" to the Government for the reform of the tax system and the public administration. ${ }^{15}$ The Act gave legal authority to implement drastic austerity measures. The decree marked the beginning of the "period of full powers" (periodo dei pieni poteri). De Stefani gained unprecedented decision-making authority. His recipe was twofold. It included tax reforms and spending cuts, and was well summarized by the motto: «"nothing for nothing": for every hundred billion of greater State income, a hundred billion less expenditures» (De Stefani 1926b, 8).

Tax controls were intensified. However, medium-high income brackets benefited from tax reliefs. A decrease in the ratio between direct and indirect tax revenue, which dropped from 0,94 in 1922 to 0,72 in 1925 , brought relative taxation burden to fall more heavily on the households with lower income (Toniolo 1980, 48). Between 1922 and 1925, duties for basic commodities grew approximately $5 \%$ per year.

The government reduced the deficit mostly through striking cuts in public expenditures: between 1922 and 1926, public spending fell from 27.6 to $16.5 \%$ as a share of GDP (Zamagni 1990). Investments were reduced in all social sectors. De Stefani appointed a committee of technical experts, called the "commission for the revision of balances and the reduction of public expenditures," that worked day and night to revise all items in the State budget . Ricci and Pantaleoni were prominent members of that commission.

The results were impressive. Drastic cuts followed in particular from the budget entry "War expenses and war employees." In three years, this entry went from 20.3 billion to 3.1 billion lira. The decrease meant a dramatic reduction in subsidies for war veterans and their families. Public investments also suffered severe cuts: "During the whole period in which Italian public finances were directed by De Stefani, the expenditures for public works continued to decrease, until, in the years 1924-1925 and 1925-1926, they reached numbers that were lower than pre-war financial years" (Cecini 2011, 333).

\footnotetext{
${ }^{14}$ See De Felice (1966); For example the economists Giretti; Nitti, Giolitti, Salvemini, De Viti and Einaudi held this view.

${ }^{15}$ Legal Decree for the Delegation of full powers to Sir Majesty's government for the rearrangement of the taxation system and of public administration. Law 1601/1922 (Official Gazette, 15 December, 1922, number 293).
} 
Budgetary rigor also drove the 1923 reform of bureaucracy (R.D 11 November 1923 n. 2395.) The public administration pursued efficiency through layoffs: more than 65,000 people were fired (De Felice 1966, vol. 1). Public services experienced the strictest "spending review". Following a press campaign that had exposed their deficits, postal and railway services fell under De Stefani's ax (Flora 1923, Einaudi 1966 vol. v-vi, Mortara 1920). The railway administration dismissed 15\% of its employees: between 1923 and 1924, 27,000 workers were fired. Regressive raise of ticket fares secured greater income. Prices of thirdclass tickets increased $15 \%$, second-class by $6 \%$, while first-class tickets were unchanged (Toniolo 1980, 50). Diminishing investment in railway track maintenance also helped improve the budget.

A large privatization of public services and State monopolies took place. Germà Bel talks of those years as "the earliest case of large-scale privatization in a capitalist economy" (Bel 2011, 3-4). The analysis of a few cases shows the drastic change with respect to the policies at the beginning of the century. For example, in 1907 the State had become the main provider of telephone services, previously owned by private firms. In 1923, a Royal Decree (399/1923, 8 February) established the conditions to grant the franchises to private providers. By 1925, the telephone sector was fully privatized. Another example concerns insurance. In 1912, the Istituto Nazionale delle Assicurazioni had been created: life insurance, previously controlled by foreign firms, would now rest in the public domain. However, on April $29^{\text {th }}$ 1923, a Royal Decree abolished the State monopoly. A de facto duopoly by private companies (Assicurazioni Generali and Adriatica di Sicurtà) began. That same year, the State even gave up the control of match sales, which it had gained in 1916.

In 1923, private firms took over the building and management of motorways. Users funded the enterprise by paying a toll. In addition to the contribution made by local governments, the State provided private businesses with annual subsidies (Bortolotti 1992, De Luca,1992).

Budget cuts, regressive taxation, public layoffs and privatizations represent the measures of fiscal austerity pursued by De Stefani. In the second half of the 1920s, monetary austerity became the government's main goal. Mussolini's famous speech in Pesaro on August $18^{\text {th }} 1926$ began the "battle of the lira." After one year, the lira had re-achieved full convertibility against gold through the Decree of 21 December 1927 and, at Quota Novanta, the exchange rate fixed against the British Pound. Revaluation triggered restrictive monetary measures, such as circulation limitation and credit cuts. 
Revaluation policy further ignited fiscal austerity measures: financial rigor was an essential condition to compensate for the increased deficit in the balance of payments. In addition to savings, wage deflation constituted a crucial variable of an economic policy coherent with currency revaluation. A stronger lira required lower labour costs, leading to lower prices and thus greater international competitiveness, which in turn had the potential to better the balance of payments. The revaluation measures promoted a solid and permanent intervention to lower nominal wages. By the 1930's «the overall nation-wide reduction of real salaries could be considered of 15-40\% with respect to 1920-1921» (Buozzi 1972). Finally, in 1927 the Labor Charter was signed: any chance for class conflict or workers' bargaining power was suppressed.

The massive economic reforms that took place during most of the 1920s are austerity policies. A contemporary observer would find it difficult to identify the difference between these measures and the structural readjustment reforms that the Troika tries to impose on Greece today. The study of austerity must examine the relationship between policy and the rationalities that shape it. The next section shows in the rationality of the post-war Italian economists the theoretical roots of contemporary austerity.

\section{Austerity Rationality}

I discuss four main "makers" of fascist austerity policies. The work of Pantaleoni, De Stefani, Ricci and Einaudi shows a remarkably common mentalite among the four, despite their different political stances: two were Liberal and two were Fascist. Yet, they shared a common vision: an austerity rationality that induced them to promote a strong government as a necessary corollary to their economic theories.

Alberto De Stefani, Maffeo Pantaleoni, Umberto Ricci and Luigi Einaudi shared social status: all were Professors of Economics and distinguished members of the academy. Moreover, all were deeply involved in current affairs. They took part in academic discussions at national and international levels and regularly contributed to domestic newspapers. Their degrees of active involvement in policy-making, however, varied. Alberto De Stefani, for example, had a leading role in shaping legislation. In 1921, after violent militancy in the Fascist movement, he became a Member of Parliament, elected in the Fascist list. From the following year until June 1925, he led the Ministry of Finance and Treasury. For the span of the decade, De Stefani continued to teach while holding many representative roles and being an engagé political observer. 
Pantaleoni and Ricci also had important functions in enacting austerity measures. As De Stefani's closest technical advisors, they participated in many governmental committees. In particular, they joined the Commission for the Revision of Balances and the Reduction of Public Expenditure. Pantaleoni, who chaired the Commission, ${ }^{16}$ had already been the representative of the Financial Commission of the League of Nations at the 1920 conference in Brussels. Appointed Senator in 1923, his political influence and scholarly international fame were well established at the time of his death in 1924. Despite being perhaps the most liberal in the quartet, the young Umberto Ricci had a long history of political activity within the Fascist government. To serve in this capacity, he was exonerated from many of his duties of professorship until the abrupt end of his collaboration in February 1925, when he distanced himself from Mussolini's regime. At the time, Luigi Einaudi was also a Senator of the Reign of Italy. From his public interventions in the press to his work as a correspondent for The Economist, it is undeniable that he fervently supported Fascist economic policy throughout the 1920 s.

Einaudi's relationship to Fascism, especially his long-lasting ideological support of the austerity rationality that Fascist government embodied, has been downplayed by many of his liberal apologists. However, it brings about one of the main points of this research. Like Umberto Ricci, Luigi Einaudi thought of himself, and was considered, the most authentic representative of liberalism. The works of both authors from those years, show a theoretical and political obsession with austerity. The same austerity, was fully embodied in the political-economic practices of 1920s Fascism, of which repressive politics were a key component. By focusing on these authors' economic thought, the ideological differences between Fascist and Liberal economists disappear. In one instance, De Stefani declared to the newspaper Il Popolo d' Italia:

I would, for example, bestow the Fascist membership card to Vilfredo Pareto, to Maffeo Pantaleoni, to Umberto Ricci, to Luigi Einaudi. The Fascist Vademecum is exactly in the oeuvres of these men; it would be good if fascists were educated in their works in order to acquire that bright unity of thought that must guide intelligent actions; in their works they would acquire the fascistic criterion for the resolution of practical problems and the essential education to tell apart a good deed from any trick or fault. (De Stefani, 1921)

${ }^{16}$ Ricci testified in the 1925 Giornale degli Economisti (republished in Ricci 1939, 19): "Maffeo Pantaleoni was a spotless and fearless citizen, a champion of many battles, which sometimes provided him with bitter enemies...I had the fortune to collaborate with him in more than one commission, in particular the one for the reduction of public expenditures in Italy, that had him as president. I saw him work without pause, day and night." 
Once in office, De Stefani confirmed his views:

When my young and bold comrades ask me how to develop a Fascist mentality, also in the technical field of social, economic and financial problems, I direct them to the works of four great Italian Fascists, who are non-militant and without a party card: Vilfredo Pareto, Maffeo Pantaleoni, Umberto Ricci and 'last but not the least' Luigi Einaudi, whom I plead my comrades to forgive if he propagandizes for Fascism on the columns of the Corriere della Sera. (De Stefani, 1922)

Was De Stefani merely paying homage to his economic masters? The rest of the paper denies this and suggest that, on the contrary, his statements had solid theoretical foundations in austerity. A thorough analysis of the mindset of Einaudi, Ricci, Pantaleoni and De Stefani reveals the nature of the consensus uniting these economists much beyond their ideological divergences.

\section{Morality, Self Sacrifice and the Virtue Of Savings}

\section{III.I Austerity: both Moral and Economic, both a National and an Individual Task.}

Austerity encompasses the economic and the moral. During a speech to Parliament in 1922, De Stefani clearly made the point:

Any effort towards greater order, a greater wellbeing and heavier influence in the balance of international forces would be vain...if this effort and fervor were not supported by the gradual but resolute financial reconstruction. Just like any other effort of reconstruction, it is the manifestation of an act of willpower that falls within the commitments of the Fascist government towards the Nation and that, as such, must be fulfilled. (De Stefani 1926b, 20)

The central idea here is an economic one: economic normalization is a precondition of any other economic achievement. Yet, the words "act of willpower" reveal a moral connotation: they show how, to De Stefani, the rhetoric of economic orthodoxy cannot be separated from the normative speech. Austere policies embody the restoration of virtue, not only of financial stability:

How ought power to be used? A deficit in the budget existed, one ought to balance it; there was public debt, one ought to pay for it; there was a devalued currency, one ought to re-evaluate it. The policy of transformative moments is not merely in these practical aims, it is the expression of ideas and of the virtues they intend to restore. (De Stefani 1927, 5, emphasis added)

This close link between economic discipline and morality recurs throughout De Stefani's speeches. Terms like "severe finance," "sacrifice," and "sacred" are constantly used. He 
spoke of the "moral balance of income and expenditures" (De Stefani 1927, 62)' and cited Mussolini's words defining financial rigor as the first "sacred commitment" of his government.

Even if the Minister considered austerity a national task, it was the individual behavior of a single citizen that had to project temperance. During a famous speech at $\mathrm{La}$ Scala Theatre of Milan, De Stefani actually used the word "austerity" to encourage individual sacrifice, in particular the renunciation of social welfare, in the name of a moral economy (De Stefani 1926b, 34). In 1919, Ricci had already referred to austerity with the same purpose: "If we, Italian people, devote ourselves to an austere existence of fatigue and savings, if we avoid being lured by economic nationalism...oh, then, in ten/fifteen years, we will be as rich as before, or even more" (Ricci 1919, 39). In short, individual behaviour is inherently moral and economic. Austerity rationality builds upon individual behaviour as its core building block.

While all of the authors consistently preached abstinence and self-restraint, Luigi Einaudi was the most passionate on the topic. He spoke of himself as "we, first apostles of the Verb of Abstinence" (Einaudi 1920, p. 173). For Einaudi, both during and after the war, savings leads to economic and moral redemption. The titles of his Corriere della Sera op-eds reveal his bias: "The teaching of saving is the highest present duty of Italians" (1916), "The duty to save" (July 7 1919), "Don't buy!" (June 19 1920), and again, in 1925, "The coming back of the sermon for saving."Two excerpts are telling:

The frugal and thrifty life, the abstinence from the excess of drinks and food has today become a necessity imposed by war. But this necessity coincides with both the collective and individual interests... War imposes the necessity to observe temperance and teaches how it is possible to live soberly, in a much nobler manner than before. (Einaudi 1920, 120)

Again:

Each one of us, with his actions, is partially responsible of what happens of evil or good in his nation...what is crucial is to save and avoid superfluous expenditure in small everyday affairs, in the name of the appreciation of the value of money. (Einaudi 1920, 46)

The dual agendas in Einaudi's discourse are clear. On the one hand, the "sermon" displays a moral content: 'Do not consume' is an imperative that draws its virtue almost exclusively from being a moral restraint, a self-obligation, a limit to useless purchase" (Einaudi 1920, 174). On the other hand, saving had several crucial economic roles to play on account of its deflationist impact on prices, as well as its being conducive to new capital formation, and, 
from there, expanded production and economic progress (Einaudi 1920, 140). Only through savings could an economy optimally function. For this reason, safeguards and incentives to save had to be the central goal of wise economic policy.

By referring to "savings-capital," Alberto De Stefani's Lectures in Political Economy perfectly summarize the common theoretical beliefs of all four authors. ${ }^{17}$ The automatic link between savings and investment lays in the behavior of economic agents: "In conclusion, the surplus or deficit of the consumer give rise to capitalistic operations [credit in order to consume] or enterprises" (De Stefani 1920, 86). An immediate association between the saver (a consumer with surplus capital) and the entrepreneur seemed to hold. Yet a question arises: does the morality of saving have an extra economic meaning? Or, conversely, is saving moral because it is economically beneficial? The matter appears unresolved in Einaudi's works. However, in Umberto Ricci's theoretical writings, a clear cut resolution emerges. ${ }^{18}$

\section{III.II Ricci and the Treble Identity}

Umberto Ricci envisaged an unshakeable conceptual triad: The economic agent is moral because he is rational; the rational agent is identified with the saver; hence, saving has a moral quality. The triad is indeed an idea he shared with Pantaleoni, De Stefani and Einaudi who considered his work on savings a theoretical benchmark. Ricci saw his writings as a contribution to General Equilibrium Theory: his theoretical goal was to refine the microeconomic analysis of savings. He assumed a distinction between ethics and morality. The former is a subjectivist sphere, made of "vague ideals of justice." Any action of individuals or public institutions that operates under the ethical ideal of social justice, in this view, pursues partisan aims. On the other side lies morality proper, which is objective and universal. It concerns the evaluation of individual behaviour, in particular, "good economic behaviour." The latter, in the form of austere behaviour (which encompasses moral values such as prudence, parsimony, sacrifice, and so on), stems from scientific considerations. The distinction between ethics and morality is crucial: contrary to ethical values, moral virtue

${ }^{17}$ De Stefani 1920, 70. While confirming that, generally, once accumulated, all economic goods can be called savings, he prefers a productivist definition of savings, which immediately involves economic transformation. Savings-capital is "that part of economic goods that one has abstained from consuming and that are used in transformations for production (seeds etc.) or, to use the ordinary terminology, in material transformation."

${ }^{18}$ Ricci published three important articles on the subject in the Giornale degli Economisti: "La teoria dell'astinenza" (1908), "L'offerta di risparmio" (1926, and "Ancora sull'offerta del risparmio" (1927), Collected in Ricci, 1999. 
descends from rational economic behaviour. In this direct relationship, the closer they are to the behaviour of the homo economicus, human beings are all the more virtuous. Savers are morally praiseworthy because they act economically.

Ricci's theory offers ample evidence of this. In his article "La teoria dell'astinenza," he argues in opposition to many critics, especially Marx, that abstinence is a crucial element of economic theory. ${ }^{19}$ Abstinence is a fundamental element of the theory of value, an indispensable one for production. It entails sacrifice: "To abstain from pleasure that it is in our power to enjoy, with the objective of remote results rather than immediate satisfaction, is one of the most painful actions for human will." This is why "amongst the tools with which man elevates his degree of civilization, it is both the most effective and the least widespread (Ricci 1999, 7, emphasis added)." Abstinence becomes a moral virtue primarily because of the economic benefits it provides, mainly, greater productivity. Only a select few, those extremely civilized and blessed men that better resemble the ideal homo economicus, have the strength to endure the sacrifice.

Ricci refined his thought by limiting any possible ethical ambiguity from abstinence, and thus from savings. He devised a mathematical notion of this economic virtue: the "virtual cost" of abstinence. The latter is measured by the subjective discount rate, which is based on the psychological rule that, ceteris paribus, present goods are preferable to future ones. The virtuous agents will have a lower subjective rate of interest and will be more prone to save:

The subjective discount rate is low for men who have an acute foresight ability and can vividly foresee future joys and needs, for energetic and disciplined men, who can endure the restraints they impose on themselves ...for men raised with sober customs. All these moral virtues - farsightedness, self-control, love for your offspring, moderate habits - together with the certainty of a long life - may render the discount rate extraordinarily small. Conversely, shortsightedness, weak willpower, proximity to death, prodigal habits, reduce the farsightedness of men, produce faded images of the future, and elevate the preference for present pleasures, therefore they increase the discount rate. (Ricci 1999, 59-60)

The homo economicus acquires this virtue of saving without any ethical sentiment. It is only a matter of rational economic calculations aimed at maximizing personal pleasure: "We believe that the homo economicus compares present pleasure to future satisfaction, properly reduced

19 "We believe not to exaggerate by saying that one cannot master the entire system of theoretical economics without first developing clear ideas on abstinence" (Ricci 1999, 14). Ricci defines abstinence as "The conduct of a person who deprives himself of a present pleasure to obtain one in the future." Abstinence and savings are directly interlinked: abstinence is the action that procures savings. In Ricci's words, "The consumption good that one renounces to, or its money equivalent, is denominated savings; thus savings is the result of abstinence. In everyday Italian however, saving is also the act of saving, and hence the words abstinence and savings are often used interchangeably," (ivi, 37). 
and discounted" (Ricci 1999, 22); "The businessman is thrifty, a thinker and a calculator, it is this real man who most resembles the abstract man pictured by economists, and he does not suffer like a wimp from the slightest thought of remote and eliminable anguish" (Ricci 1999, 22). Ricci alludes to the homo economicus who is rational by definition. This figure finds his equilibrium in saving when "the marginal cost of saving equals its marginal instrumental utility" (Ricci 1999, 59). Through his cold and farsighted calculations, the economic agent attains the moral virtues that Ricci, like the three other authors, so admired.

\section{III.III. Repression}

At this point, the reason why the normative essence of austerity rationality has an intrinsically repressive effect on the individual becomes clear. To resemble the virtuous rational agent, one must abide by the behavioural norm of strict self-control. Austerity becomes a technique of power: it imposes on human life an obligation for self-discipline through the subjective internalizing of the need to approximate virtuous homo economicus. ${ }^{20}$

The repressive nature of this obligation is perceptible in post-war politics. To all four scholars, it was the middle and the upper classes that had truly undergone sacrifice by saving during and after the war. ${ }^{21}$ This elitist view, for Pantaleoni, is inseparable from his Social Darwinistic perspective. $^{22}$ In a free-market society, economic selection allowed for the most rational agents to strive. Class differences followed from different moral and intellectual endowments: “'Bourgeois' is whoever has the moral and intellectual value required to be such: he who lacks talent, activity, perseverance, control of his own passions and impulses, stops to be a Bourgeois; these qualities are all required to emerge amongst comrades and dwell in a class that is not that of the plebs" (Pantaleoni 1922, 109). On the other hand, the working class suffered from incurable vices, such as wasteful consumption. The usual rhetoric applied: war had brought undeserved wealth to workers thanks to higher salaries; yet

${ }^{20}$ In this perspective the concept of "government" has a wide-ranging meaning that is not merely political. It particularly refers to the subjectivisation process: it is the "conduct of conducts," meaning that ranges from governing others to governing the self (Foucault, 1982).

21 "In truth the middle and the property owning classes saw their income diminish...yet they still sacrifice in the name of savings," (Einaudi 1920, 96). Even in the case of war super-profits, industrial capitalists serve the general economic interests by either investing in new capital or underwriting state loans: "One must keep in mind that if some industrials, landowners and retailers earned more than before due to the war, in the interest of all they had to invest their super-profits (reduced by taxes) in the enlargement of plants and machinery, which were required by the army"; and given that war needs had reduced the general means for subscribing to public debt, "the industrials who gave the example of large subscriptions were even more praiseworthy," Ibidem.

${ }^{22}$ On Pantaleoni’s Social Darwinist perspective: see Bini 2013. 
workers, rather than save, had indulged themselves into moral and economic decline. As Pantaleoni $(1922,58)$ explained:

The working classes basically don't save and spend everything in pleasures, with the consequence of a remarkable decay of their moral qualities. In my judgment, as a consequence of the laws and actions of Government, their salaries are much higher than the marginal return of their labour. This is the outcome, first, of the pressure of the war, and, then, of the pressure of socialism and Bolshevism. This state of affairs will necessarily lead to collapse, because it is paroxysmal to capitalism and an obstacle to new savings and the growth of production.

And again:

Thanks to Bolshevism, the modesty in the standard of living that characterized Italians has vanished. It has disappeared in both the working class and the peasantry. It is disgusting to witness the masses of workers that are drunken in all our cities, like, to my direct observation, Genoa and Rome. The noteworthy increase in salaries has not been accompanied by greater civilization, hence the worker and his spouse live like pigs in their homes in order to waste the greatest part of their income in wine at the tavern. (Pantaleoni 1922, XIV).

The allegedly more liberal Einaudi betrayed a highly classist attitude - and a special attention to alcohol expenditures:

It is well know that the salaries of workers in the industrial and commercials areas of Italy have increased noticeably ...the need to save is felt by the peasant, whose class is the most thrifty; maybe it is not likewise felt by the worker, the evidence being the conspicuous increases in unnecessary consumption of alcoholic drinks, of sweets, chocolate, and biscuits, about which manufacturers could give us some pertinent data (Einaudi 1920, 97).

Our economists distrusted, and perhaps despised, the working class, its main sin being ineptitude for the vital action of economic progress: saving. Despite their ineptitude, workers had actually gained economic and political power. These historic gains were morally and economically detrimental. Hence, they had to be opposed. In "Una causa della crisi italiana"(republished in Pantaleoni 1922), Pantaleoni even spoke of the unlawful economic power gained by the working class as the primary cause of the post-war economic and financial crisis. What made workers' power a violation of the (economic) law was that it did not stem from economic selection, but from illegitimate government support.

Austerity rationality, with its individualistic inclination, asks agents to undertake a specific behavior: self-sacrifice and prudence, of which only certain citizens are able. It is therefore up to the upper class, for both moral and (in Pantaleoni's case) evolutionary reasons, to lead society toward the achievement of economic efficiency. For Pantaleoni economic efficiency is equated with evolutionary survival. 
If necessary, the austerity rationality must be forced upon a recalcitrant working class. Since the majority of citizens had degenerated into the wrong conduct, a strong government was the only chance for austerity to prevail.

\section{The Strong and Technocratic Government}

Fascist and liberal economists shared the political ideal of a government made up of economic experts who acted according to the austerity rationality. Technocracy paired well with the crucial characteristics of austerity: its self-portrait as absolute, objective and universal truth. The policies necessary to validate economic principles - such as austerity are true, neither political nor pursuant of any partisan interest. This is why it is the role of experts to define and implement them.

De Stefani, in front of the English Institute of Bankers, exemplifies the austerity rationality: "We still judge sound finance by the strict adherence of government practice to those laws that are not political, but natural and human; and in all countries the people are inexorably forced to pay the penalty for disobeying them" (De Stefani 1927, 316). He reiterated this idea in many other circumstances: "Once more we learn that, even if they required case-by-case application, the directives of financial technique are universal and constant" (De Stefani 1998, 147).

In De Stefani's view, economists must support the policy that enables the most direct implementation of economic laws. Since all four authors viewed the post-war political situation as horrific, they saw no possibility for a spontaneous or painless economic "redemption." Pessimism seeped from Pantaleoni's memorandum at the Brussels Conference:

The possibility that governments will stop their interference and confine themselves to their proper function - which consists in guaranteeing the general conditions within which private initiative can be conducted - is quite feeble because public opinion and the powerful interests of bureaucracy and routine wrongly support them. (Pantaleoni 1922, 51)

Our economists were tormented by the democratization process that the war brought into action. They considered social reforms favorable to workers to be nothing but instances of Bolshevism that subverted economic order by "squandering the public revenue." (Einaudi 2000, 229, [1921]..$^{23}$

23 "Any application of the eight-hours-a-day policy, and of the weekly rest, by which the time of effective work was sometimes reduced to two or three hours a day, is largely responsible for this lamentable state or affairs; but lack of discipline contributed no less to it," (Einaudi 2000, 270, [1923]). 
The most vocal critic of the post-war situation was Luigi Einaudi. He worried about obstructionism, factory occupations and the transformations of industries into cooperatives. In 1919, he wrote:

We live in times of overexcitement. The end of the war abolished that moral compression that compelled each citizen to restrain himself, to wait with patience, to limit his desires. Once the brakes are released, aspirations find full-scope, desires are unbridled. Everyone seems to have the urge to live life anew... Hence all classes are restless, all want something more than what they have, not just the increase of monetary salary or just the decrease of working hours, but all this as a means to obtain more pleasures, to live a more intense life. (Einaudi 1966, V, 144)

Once Fascism gained a majority in Parliament, Einaudi stated:

Before this vigorous counterattack occurred in Italy against Bolshevism imported from Russia, the victory of socialism seemed too close and too easy. It was the time in which one would speak of the Bourgeoisie as a corrupt social class; in which it seemed that a shoulder shove would suffice to knock the so-called capitalism regime to the ground. The communistic millennium seemed near; the reign of equality close to ensue. (Einaudi 1966, VII, 905)

To win the hard battle for austerity, a technocratic government is necessary but not entirely sufficient. The Italian government must also be "strong." No confusion should be made: by strong government our authors did not just mean a Government with economic leverage. Rather they envisioned an authoritarian "law and order" Government, which never hesitates to use repression against the people in order to protect the market economy. A strong Government must protect the private productive forces of society against all suspicious Bolshevism and egalitarian inspirations of social justice. Thus, the State could achieve its proper and ultimate role: safeguarding the market.

While Pantaleoni's violent inclination is well known (Michelini 2011), it was the liberal Ricci who called for repression during the tumultuous post war-years. Confronted with uprisings against merchants, Ricci wrote:

Nitti could either repress the uprisings or reestablish the censorship that had been hastily abolished. To repress the revolt, or better, to oppose the vandalistic fury, would have been easy, at least at the beginning. Instead public forces were left with no instruction. (Ricci 1920, 11)

For his lack of resolve and inability to repress social forces, Nitti embodied the helpless economist that has betrayed his gospel by committing himself to politics. He was accused of "insincerity, carelessness, weakness" (Ricci 1920, 47). Einaudi, the other liberal champion, complained of the weakness of Giolitti's and Nitti's post-war governments. To him, Italians 
were "oppressed by the absolute rule of an old, ineffectual, compromising, skeptic set of politicians" (Einaudi 2000, 267, November 27, 1922).

They all were aware of the radical political changes caused by war: the weakest social classes claimed greater support from the State, and the institutionalized democratic system entertained their demands. To succeed, austerity measures needed a top-down effective decision-making process, such as what Mussolini would eventually provide. There must be quick and ruthless action; the Fascist movement seemed up to the task. The inefficient democratic dialectic ${ }^{24}$ didn't fit this purpose. During a 1921 interview with Il Popolo d' Italia, De Stefani admitted:

The question regarding the new orientation does not exist, or at least it does not exist in my own spirit: the axis of Fascism is the one of two years ago, when Fascism had a more definite expression because it was expressed in action, and not like today, too often distorted by the usual dialectic of certain fascists, whose lawyerish spirit, of the prevailing democratic tendency, has buried that spirit of silence and action, the action that should be common to our ranks. (De Stefani 1921, 3)

Most scholars see De Stefani's ministerial action as the emblem of the normalization phase of Italian Fascism (Marcoladi 1986, 18, Toniolo 1980, 50). De Stefani's above declaration in the press, however, shows a deep ideological continuity between normalizing austerity policies of the 1920s and the violent, anti-democratic popular uprisings of the Fascist movement.

Einaudi's 1921 report in the Economist shows that such a deep continuity between austerity and political repression was true not only for Fascist economists but also for austere liberals. Indeed, the narrative of the observer for the English press glossed over the murderous actions of the "Fascist action squad" who were beating, killing and torturing political opponents throughout the country. ${ }^{25}$

When the worst happened, in September last, and the occupation of factories by armed workers and the institution of Soviets in factories seemed to point to an imminent Communist revolution in Italy, and the Government declared its impotence to use the armed force for the enforcement of the law, a sudden revolution took place. Youths of the middle class, returned men and officers, in indignation grouped themselves into "fasci." In recent months, and even today, newspapers are full of reports of encounters and fights between "fascists" and "communists." The communists are everywhere defeated; public opinion is rising against the idols of November, 1919...This renewed feeling of hope in

24 "Democracy and universal suffrage are synonymous with the rule of the ignorant masses", who cause the expansion of public intervention in the economy: "The enlargement of the State, the blow-up of its functions, the management of this State by the most ignorant, the most incompetent: this is democracy, as long as it arises in weakened from; it is socialism when it presents itself in virulent form. In this case we find ourselves in a Butualà regime," (Pantaleoni 1922, 269).

${ }^{25}$ On the Fascist squads and their violent actions: Vivarelli,1991; Tasca, 1975; Maier, 1975. 
the future of our country is not the least important cause of the better tone in foreign exchanges. A while ago Italy seemed likely to be the first country to tall a prey to Muscovite communism and barbarism; to-day the nightmare is gone and gone forever. (Einaudi, 2010 [1921], 191-192) ${ }^{26}$

Almost inevitably, all four authors thought of Fascism as the eagerly invoked "new political class" (Einaudi 1966, V, 863) made of a "set of politicians, young, energetic, full of vigor and of patriotism," who would finally prove determined enough to go against the will of the masses and impose austerity. The questions that Einaudi posed on the exact day of the march on Rome (28 October 1922) are very telling:

The important question is what is the economic platform of the new party? Signor Mussolini, the chief, is not an economist. Passionate and full of vigor, he is able to commit his party to headlong plunges into unknown seas. For the moment, he has uttered at Naples only one economic sentence: "Italy needs at the helm a man capable of saying no to all requests of new expenditure." So far, so good...public opinion was seriously and gravely warned of the necessity of putting an end to the increase in public expenditure, and of reducing even useful expenses ...Will the new Party have the will and the power to redress the awkward financial situation of the State, which is the only true cause of the present unfavorable movements of exchanges and prices? (Einaudi 2000, 263, October 28, 1922)

Expectations were met: Mussolini surrounded himself with economic experts and initiated a long string of austerity policies. ${ }^{27}$ Einaudi's commentary is the ultimate proof of the connection between austerity and strong government:

The first financial acts of the Fascist Government are promising...the most important act of the new Cabinet has been its demand for provisional powers to collect and expend revenue until June 30, 1923. The Government is thus empowered to act as if the budgets had been regularly discussed and voted by Parliament. Moreover, the Chamber has passed the so-called Bill of fullpowers. The Senate will certainly concur. This Bill authorizes the Government until December 31, 1923, to reform the civil and military services; to suppress this or that public service; to transfer railways and the other industrial State concerns to private hands; to reduce, simplify, or increase existing taxes, and to introduce new ones; to act as they will in the domain of public administration and finance. Never was such absolute power entrusted by a Parliament to the Executive. Even in time of war there were limits to the free action of the Government...The renunciation by Parliament of all its powers for so long a period was received with general cheers by the public. Italians were sick of talkers and of weak executives. The general feeling is one of

\footnotetext{
${ }^{26}$ On Il Corriere della Sera, Einaudi eulogizes the agenda of the PNF (National Fascist Party) congress of Naples 22-24, October 1922. Einaudi testifies that De Stefani's orthodox economic agenda is exactly the one he has been preaching in his press interventions (Enaudi 1966,VI, 921).

${ }^{27}$ Einaudi's enthusiasm for the Fascist austerity is also documented by his articles in The Economist: Einaudi (2000 266, November 27, 1922 and, 269, December 31 1923).
} 
profound distrust towards Parliament. Men would accept a Czar for the sake of getting out of chaos. (Einaudi 2000, 266, November 27 1922)

As for Ricci, even after Fascists had gained power, he argued for harsh social repression and the government's authoritarian sense of resolve as necessary conditions for financial reform. Moral and intellectual determination were not enough to combat social forces:

But neither clear-sightedness, moral integrity and the courage of the Minister [De Stefani], nor intelligence and the technical capacity of major and minor officials who follow him with affection and respect, are enough. The battle will be harsh: it has already started...The abolition of public deficit is not work of a day or of a person. It is a work that calls for the strain of the whole Italian people: one must learn not to ask and to applaud at the Minister who does not allow. (Ricci 1923, 612)

A final remark conclusively establishes the connection between austerity and repressive politics. The four economists were not infatuated with Mussolini's charismatic figure per se, but rather they saw Mussolini as the right man at the right time to implement orthodox economics. The authors did not hesitate to criticize Mussolini's policies when they did not conform to austerity tactics. For example, in an article on La vita Italiana (1921), Pantaleoni condemned Mussolini's mistakes when Il Duce was found sympathizing with socialist parties (Einaudi 1966, VI, 897; Pantaleoni 1922, 215). Einaudi was concerned with some initial, seemingly Bolshevik manoeuvres of the Fascist party. Nevertheless, thanks to De Stefani's agenda, austerity took hold.

At this point a legitimate doubt arises: was this call for repressive politics merely a reaction to the post-war social uprisings and economic crisis? Through the study of the academic production of our economists we may refute this simplistic explanation, and outline the true reason for the repressiveness of austerity.

\section{Nature of Economics and the Economist's Role}

It is time to look into the awareness the authors displayed regarding their role as economists. While Umberto Ricci covered the topic most extensively, the writings of Einaudi, De Stefani and Pantaleoni reveal that Ricci expressed an outlook common to all four.

According to Ricci, the economist has the tough but vital task of being the super partes guide for the redemption of austerity. He must educate humanity to the correct economic behaviour in order to bring forward economic equilibrium and progress. Ricci gave 
two important speeches on the matter: in Pisa for the opening of the academic year 19211922, titled "The alleged decline of political economy," and at the University of Bologna in January 1922, called "The unpopularity of political economy." In both occasions he conceded that ignorant and opportunistic masses hated economists and viewed them as public enemies (Ricci 1926, 1, 72). His rhetoric properly conveyed the idea of the economist under siege by brutal and irrational citizens. Austerity policy was especially loathed: "By proclaiming the principle of universal taxation, promoting the shutdown of useless public offices, the dismissal of redundant employees, the abandonment of public works, the economist surely doesn't make new friends" (Ricci 1926, 102).

The economist should never be discouraged, however, because in his purity he is spiritually gratified. In the conclusion of the Bologna speech:

Not always [the economist's] words are listened to, not always the conscience of accomplishing his duty is accompanied by the joy of the result. But if sometimes he is affected by the sorrow of having spoken in vain, a reward awaits him, one that no human force may subtract from him. As he progressively climbs the ivory tower, and abandons at each floor his prejudices and interests, his vision gets ever more refined, his horizon is enlarged; eventually, when the high summit is reached, he discovers the unity in the truth, the order in the disorder...and the spectacle from the high tower becomes even more marvelous when, in the exchanges among firms, groups, classes and nations, one is capable of distilling rigorous and elegant laws, worthy of competing with the laws of celestial mechanics. This vision of beauty is the economist's sovereign reward. (Ricci 1926, 104-105)

All four economists shared this intellectually elitist position, a belief that stemmed from their conception of the nature of economic science. A description of this meta-economic perspective offers a fuller understanding of the repressive nature of austerity.

The authors shared a positivist view of economic knowledge: economics was a rigorous and universal science, with the same epistemic legitimacy of other hard sciences: "The socialist and the protectionist are to the economist like the astrologist to the astronomer, the alchemist to the chemist, the sorcerer the doctor" Ricci wrote $(1926,25){ }^{28}$

De Stefani and Ricci considered themselves as direct disciples of Pantaloeni ${ }^{29}$, who was internationally recognized among the founding fathers of "pure economics," ${ }^{30}$ the discipline that truly brought economics to the height of all other objective sciences:

\footnotetext{
${ }^{28}$ Einaudi's scientific work was more of an applied nature, especially regarding taxation and financial science. However he expressed full consensus with the meta-economic approach of pure economics.

${ }^{29} \mathrm{I}$ am aware that controversy exists amongst scholars on the degree of "purity" of Pantaleoni's theory by the 1920s. Michelini observes that in Erotemi, the most important collection of Pantaleoni's economic theory in that decade, two Pantaleonis seemingly coexist: the author of Pure Economics and that interested in economic
} 
Pantaleoni saw something that today is more than obvious, that is, that there must be a theoretical part of economic science, a nucleous of doctrines, that are independent of opinions, as well as of ethical, political and religious predilections. Something similar to physics and mathematics, something that is science for Italians, for English, for the brunets, the blonds, the socialists and for the individualists: this is "pure economics"... Pantaleoni appeared as the archangel with the flaming sword, to do justice against all false schools and proclaim pure economics sovereign. (Ricci 1939, 44) ${ }^{31}$

"Pure economics" reaches truth status by using mathematical tools and an analytically deductive method to investigate the phenomenon of economic equilibrium. It is based on logic. The outcomes of these experiments lead to rigorous laws: given certain premises, the fundamental economic theorems follow. ${ }^{32}$ The universality of economic theorems allows disregard for the institutional and historical-relative character of economic phenomena. ${ }^{33}$ It follows that pure economics is endowed with normative neutrality, confirming its universality and analytical power.

Pure economics aspires to excellence of Platonic form. Yet, austerity rationality occupies the space between theory and practice. How can pure economics be relevant to its analysis? The four economists were engagés precisely because, despite its "purity," economics has an undeniable practical aim. Thus, we can reconcile the economists' frequent interventions in public conversation or in policy-making, with their self-portrait of champions of universal economic truths, in the interest of all, in denial of being politically driven.

The four agreed with a famous passage of Pantaleoni's magisterial book, which emphasised economic theory as a prerequisite for policymaking:

First of all, one must be well-read in pure economics, then trained in applied economics, that is, pure theory; finally one can embark on the resolution of

dynamics and the sociology of economics. However, what is relevant for the present paper is that Ricci and De Stefani clearly praised just one Pantaleoni: the "arcangel" of Pure Economics, the work that bestowed him scholarly fame, both nationally and internationally.

${ }^{30}$ Pantaleoni's Principii di Economia Pura (translated as Pure Economics) had vast scientific impact. Apart from its contribution to international scholarship, the book was a theoretical and methodological turning point for economic studies in Italy, paving the way for the Marginalist School. On the point: Barucci,1980.

${ }^{31}$ Note that Ricci did not distinguish between pure economics and political economy: "Like any other science political economy is a logical system made of rigorous definitions and laws; and a law expresses a necessary connection between two facts. Any law can by schematized as: "If fact A happens fact B happens." In this system, the fundamental concept is price, to which all other economic concepts are connected," (Ricci, 1925).

32 "Logic knows direct operations and inverse operations; this is why we have both in each science. A direct operation is one by which, once the premises and the laws of logic (by which the premises should function) are given, the conclusion may be searched, and there is but one...Any treatise of economics is nothing but an ensemble of direct operations," (Pantaleoni 1963, 154).

33 "Econonomic progress is essentially based upon ever greater abstractions and generalizations that enable to approach any economic problem by using the same criteria, which, in the end, is that of the maximization of individual utility, both in the case of the producer, of the consumer and the saver," (Pantaleoni 1963, 165). 
concrete economic problems, that is, the peculiar and contingent issues that everyday reality puts under our eyes and whose core is economic. (Pantaleoni 1963, 45-46)

In short, the models and theorems must dispense practical economic knowledge. During a dispute in the Giornale degli economisti against W.J. Ashley, a leading figure of the British historical school, Ricci wrote:

If there is intransigence anywhere, purists are not to be blamed. What is dangerous is only the narrow-mindedness of those who reject abstraction and deductive reasoning and linger in monographic and fragmentary historical researches on economic institutions. It is the honest desire of any good theorist of political economy that theoretical constructions be deemed not merely a luxury of the intellect, but necessary to explain and forecast events, and essential to tame men. (Ricci 1908, 389, emphasis added)

Even if economics as a science is pure and abstract, at its core it has an epistemological rightof-way over individual behaviour and thus over economic political reality (which, in this individualistic perspective, is merely an aggregate of individual behaviours). As Piero Bini put it, an "idealisation" of the relationship between theory and policy emerged, in the form of "a continuation of scientific knowledge into practical action" (Bini 2004, 306).

My close-scrutiny of their works reveals that the pre-eminence of economic principles over the concrete practice of human beings is due to a sturdy ontological foundation: Pure economics' epistemological priority over reality descends from its reference to real-life facts. In fact, abstraction brings formal exactness, yet correspondence with the real world is not lost. Ontological realism and ontological universalism give legitimacy to pure economics, and thus to the policies stemming from it.

The hedonistic principle is the peculiar characteristic of the homo economicus and the founding element of pure economics. It is understood as a real life phenomenon that economists understand in a formal manner. Pantaleoni's second chapter of Pure Economics extensively discusses how the hedonistic principle is the sole realistic guide for human behaviour. ${ }^{34}$ His disciple De Stefani taught the same to his students: "The fundamental law of conduct, which is revealed through observation, is the law of minimum sacrifice and maximum self-interest: economic progress is the historical explication of this universal norm of economic conduct," (De Stefani1920, 4).

\footnotetext{
34، The proof of the existence of the force postulated by economics is supplied both by self-observation and by observation of the motives from which other men act...Above all, it is evident that commercial or industrial activity, or the activity (whatever its nature may be) displayed by men in the pursuit of what is commonly termed wealth, has no other motive than egoism," (Pantaleoni 1898, 11).
} 
The maximising conduct of the homo economicus brings about individual equilibrium and, through aggregation, the general equilibrium of the economy. Hence, even general equilibrium - that quintessential theoretical construction - is a fact of the real world:

The recent theoretical progress of economic studies precisely consists of an ever more general formulation of the concept of economic equilibrium, to which is connected an ever more rigorous inductive and statistic study of the reciprocal dependences among the circumstances that determine that same equilibrium. This equilibrium is a fact, just like the equilibrium of our organism, or of any other organism or system one may think about. (De Stefani 1920, 8, my emphasis)

In sum, the absolute epistemic and ontological authority of economic science over human lives is the basis of austerity rationality.

This meta-economic analysis captures the core reason of the repressive nature of austerity. Its oppressiveness derives from the intellectual subordination of human beings to economic laws, that is, to a regime of universal and objective truth. Such repression is primarily due to a methodological reason. Economic categories, short from remaining theoretical constructions, represent direct counterparts to the real world. The upshot is truly repressive: abstract categories acquire ontological primacy over the life of individuals. This is why budget cuts and monetary deflation may become the main concern of austerity: the purpose is to adapt reality to fit the categories of economic equilibrium and progress in a competitive economy. The concrete needs and purposes of flesh-and-blood citizens are not a priority.

Moreover, the premise for the repressive mechanism occurring at the individual level (see above, section III.II-III.III) are located in this meta-economic conception. The trinomial rationality-morality-saving is the result of the fetishism of the homo economicus: ${ }^{35}$ the four economists did not recognize the latter as an abstraction. They would rather deem it a real fact. This reasoning produces a discourse that has the truth effect of becoming reality: the individual ends up perceiving himself as a homo economicus. Self-repression serves to fit this category to the fullest. Social problems such as poverty, unemployment and illness become a matter of individual responsibility, whose main cause resides in the agent's unorthodox - i.e., non-economic - conduct. The function of strong government is to blame and punish those

${ }^{35}$ In Marxian theory, fetishism is the methodological error, which becomes ontological, of thinking of categories constructed by a particular economic-political practice as natural and intrinsic to objects or people. In the market economy, fetishism of the price (exchange value) occurs because economists consider it a fact, instead of realizing that it is the result of subjective relations of production. See Marx (1906), Part VIII, Vol I. 
that do not self-repress. Foucault would say that the deeper consciousness of the Self is obstructed and controlled (Foucault, 1982).

The idea that "rational means moral" bestows normative strength to austerity rationality. Nonetheless, the oppressive nature of austerity would subsist even if the right economic behavior had been considered amoral. In fact, economic categories achieve absolute preeminence in shaping the policies that affect material life. This practical outcome is due primarily to an intellectual motivation: economists have given theoretical priority to economic models. They are trapped in "negative" ideology, ${ }^{36}$ and thus lose the awareness that the true genealogy of the "economic" lies in the subjective and material life of human beings. A structural conflict between human life and economic theory and policy ensues.

Going back to De Stefani's La Scala speech, we may finally understand why he used the word austerity. He employed it to encourage individual sacrifice and, in particular, the giving up of social protections in the name of the State's superior financial needs:

In the speech of the 25 th of November I reminded the Parliament that, right after the march on Rome, the awareness of the financial necessities of the Nation were widespread, even in the most humble part of the Italian population. Today, as yesterday, I need to place on the national agenda the conscious renunciation of the rights gained by the crippled, the invalids, the soldiers. These renunciations constitute for our soul a sacred sacrifice: austerity. (De Stefani 1926b, 34, My emphasis)

\section{Conclusion}

Austerity is a robust heuristic to analyze the first, so-called "liberal phase" of Fascist Italy. The conceptual precondition is to go beyond the ahistorical tale of austerity as the post1980, neoliberal economic theory of price deflation and budget cuts. Austerity must be conceived as a holistic rationality, a regime of truth that is intrinsically, and simultaneously, theory and practice, encompassing the moral, the economic and the political.

This study shows that the economic reforms undertaken by the Italian Fascist Government in the 1920 s were, in essence, austerity policies. Austerity served to eradicate the socializing trend of the immediate post-war years. This was no accidental result: the fear of economically inefficient democratization processes was a founding element of the

\footnotetext{
${ }^{36}$ It is worth reminding here that the Marxian meaning of ideology is twofold: 1) ideology in the positive sense, i.e., the collection of conceptual representations at whatever level of sophistication: no conceptualization is independent from the subjective and historical reality which creates it; 2) ideology in the negative sense, i.e., the non-recognition of the real and historical foundation of a conceptualization: hence the tendency to universalize (Geuss, 2008, Henry, 1991).
} 
rationale of the fathers of the Fascist reforms. In the name of austerity, Fascist economists De Stefani and Pantaleoni joined forces with liberals Ricci and Einaudi. Firsthand analysis of their engagés and academic production confirms the fundamental relation between austerity and repression.

The rise of Fascism endowed the academic economists with unprecedented political powers: they found in the new regime the historical opportunity to implement their austerity rationality. More than elevating rigor to be the single goal of monetary and fiscal policies, this meant achieving full consistency with their deeper meta-economic understanding. Italian economists were engagés precisely because they saw themselves as the guardians of a universal economic science - a science that, despite its purity, had an intrinsic practical aim. Meta-economic analysis reveals the core reason for the repressive nature of austerity. Oppressiveness derives from the ontological subordination of human beings to economic categories that have priority over flesh and blood needs. In the explosive post-war era of upheavals and redistributive demands, when citizens of many European countries were ever more distancing themselves from the identity of the moral-rational-saver, the only concrete solution for them to comply with the austerity rationality was through a repressive, technocratic government that De Stefani, Pantaleoni and Ricci joined, and Einaudi supported.

\section{References}

Alber, J. 1983. "Lo sviluppo della assicurazione contro la disoccupazione nell'Europa occidentale." In Lo sviluppo del welfare state in Europa ed in America, edited by Flora Peter., and Arnold Heidenheimer. Bologna: Il Mulino.

Alberti, Manfredi. 2013. La scoperta dei disoccupati. Firenze: Firenze University Press.

Barucci, Piero. 1980. "La diffusione del Marginalismo 1870-1890." In Il pensiero economico italiano 1850-1950, edited by Massimo Finoia. Bologna: Cappelli.

Bel, Germà. 2011. "The First Privatization: Selling SOEs and Privatization of Public Monopolies in Fascist Italy (1922-1925).” Cambridge Journal of Economics 35, 5: 937-956.

Berta, Giuseppe. 1993. "The Interregum: Turin, Fiat and Industrial conflict between war and fascism." In Challenges of Labour, edited by Chris Wrigley. London: Palgrave.

Bini, Piero. 2000. "The Making of Economic Policy in Italy in Inter-wars Years (19221940)." Storia del Pensiero Economico. 40: 5-30.

Bini, Piero., and Antonio Maria Fusco. Eds. 2004. Umberto Ricci (1879-1946):economista militante e uomo combattivo. Firenze: Polistampa. 
Bini, Piero. 2013. "Captains of Industry and Masters of Thought. The Entrepreneur and the Tradition of Italian Liberal Economists from Francesco Ferrara to Sergio Ricossa." Rivista italiana degli Economisti. 18, 1: 87-130.

Blyth, Mark. 2013. Austerity the History of a Dangerous Idea. Oxford: Oxford University Press.

Bortolotti, Luca.1992. "Origini e Primordi della Rete autostradale in Italia, 1922-1923." Storia Urbana 16, 59: 35-70.

Buozzi, Bruno. 1972. Le condizioni della classe lavoratrice in Italia. Milano: Feltrinelli.

Campbell, Jones., Martin Parker and René ten Bos. 2005. For Business Ethics. New York: Routledge.

Cecini, Stefano. 2011. "Il Finanziamento dei lavori pubblici in Italia. Un confronto tra età liberale ed epoca fascista." Rivista di Storia Economica. 27, 3: 325-364.

Ciocca, Pierluigi., and Gianni Toniolo, eds. 1976. L'economia italiana nel periodo fascista. Bologna: il Mulino.

Ciocca, Pierluigi. 2007. Ricchi per sempre? Una storia economica dell'Italia 1796-2005. Torino: Bollati Boringhieri.

Dardot, Pierre and Chrisitan Laval. 2009. La nouvelle raison du monde. Paris: La Découverte.

De Luca, Giuseppe. 1992. "La costruzione della rete autostradale italiana: L'autostrada Firenze-mare, 1927-1940.” Storia Urbana 16, 59: 71126.

De Felice, Renzo. 1966. Mussolini il Fascista. La conquista del potere, 1921-1925. Torino: Einaudi.

De Stefani, Alberto. 1920. Economia Politica appunti. Padova: La Litotipo.

-----.1921. "L'orientamento del Fascismo secondo il pensiero di Alberto De' Stefani." Il Popolo d'Italia, September 21.

-----.1922. "Accertamenti finanziari. Pubblicità dei redditi imponibili". Il Popolo d'Italia, January 14.

-----. 1922. L'azione dello Stato Italiano per le opere pubbliche (1862- 1924). Roma: Libreria dello Stato.

-----. 1926a. La legislazione economica della guerra. Bari: Laterza/ New Haven: Yale University Press.

-----.1926b. La Restaurazione Finanziaria 1922-1925. Bari: Laterza. 
-----.1927. Le vie Maestre. Milano: Treves.

Einaudi, Luigi. 1920. Prediche. Bari: Laterza.

----. 1959-1965. Cronache economiche e politiche di un trentennio. Torino: Einaudi Editore.

-----. 2000. From our Italian Correspondent, Luigi Einaudi's articles in the Economist, 19081946. Edited by Marchionatti. Firenze: Leo S. Olschki publisher.

Faucci, Riccardo. 2014. A history of Italian Economic Thought. London: Routledge.

Flora, Federico. 1923. La politica economica e finanziaria del Fascismo. Milano: Imperia.

Foucault, Michel. 1982. "The Subject and Power.” Critical Inquiry 8, 4: 777-795.

-----. 2008. The Birth of Biopolitics, Lectures at the Colège de France 1978-1979. New York: Palgrave.

Frascani, Paolo. 1975. Politica economica e finanza pubblica in Italia nel primo dopoguerra. Napoli: Giannini.

Geuss, Raymond. 2008. Philosophy and Real Politics. Princeton: Princeton University Press.

Henry, Michel. 1991. Marx: Une philosophie de L'économie. Paris: Gallimard.

Konzelmann, Susan. J. 2014. The Economics of Austerity. Cheltenham: Eduard Elgar.

Lemke, Thomas. 2000. "Foucault, Governmentality, and Critique." Paper presented at the Rethinking Marxism conference, University of Amherst, September 21-24.

Marx, Karl. 1906. Capital a Critique to Political Economy. Edited by Frederick Engels. New York: Modern Library.

Michelini, Luca. 2011. Alle origini dell'antisemitismo nazional-fascista. Maffeo Pantaleoni e "La vita italiana" di Giovanni Preziosi 1915-1924. Verona: Mondadori.

Mortatara, Giorgio. 1920. Prospettive economiche della guerra. Città di Castello.

Mussolini, Benito. 1933, Discorsi. Verona: Istituto Italiano di Credito Marittimo.

Pantaleoni, Maffeo. 1898. Pure Economics. New York: Macmillan.

-----. 1922. Bolscevismo Italiano. Bari: Laterza.

-----. 1963-64. Erotemi di Economia. Padova: CEDAM.

Ricci, Umberto. 1920. La politica economica del Ministero Nitti. Gli effetti dell' intervento economico dello Stato. Roma: La voce.

-----. 1925a. Lezioni di economia politica, 1924-1925. Roma: Università di Roma, Libreria della Sapienza di A Sampaolesi. 
-----. 1926. Dal Protezionismo al Sindacalismo. Bari: Laterza.

-----. 1928. "La scienza e la vita.” Nuovi Studi di Diritto, economia e politica: 220-225.

-----. 1939. Tre Economisti Italiani Pantaleoni, Pareto Loria, Bari: Laterza.

-----. 1999. Saggi sul Risparmio. Lanciano: Carabba.

Tasca, Alberto. 1965. Nascita e avvento del Fascismo. Bari: Laterza.

Toniolo, Gianni. 1980. L'Economia dell'Italia Fascista. Bari: Laterza.

Vivarelli, Roberto. 1991. Storia delle Origini del Fascismo. Bologna: il Mulino.

Zamagni, Vera. 1976. "La dinamica dei salari nel settore industriale". In L'economia italiana nel periodo fascista," edited by Ciocca, Pierluigi., and Gianni Toniolo, Bologna: il Mulino.

1990. Dalla periferia al centro. La seconda rinascita economica dell'Italia 1861-1990.

Bologna: Il Mulino. 
